\title{
Established and emerging factors affecting the progression of nonalcoholic fatty liver disease
}

Stergios Kechagias, Patrik Nasr, J ulia Blomdahl and Mattias Ekstedt

The self-archived postprint version of this journal article is available at Linköping University Institutional Repository (DiVA):

http:/ / urn.kb.se/ resolve?urn=urn:nbn:se:liu:diva-170975

N.B.: When citing this work, cite the original publication.

Kechagias, S., Nasr, P., Blomdahl, J ., Ekstedt, M., (2020), Established and emerging factors affecting the progression of nonalcoholic fatty liver disease, Metabolism, 111, 154183.

https:// doi.org/ 10.1016/j.metabol.2020.154183

Original publication available at:

https:// doi.org/ 10.1016/j.metabol.2020.154183

Copyright: Elsevier

http:// www.elsevier.com/

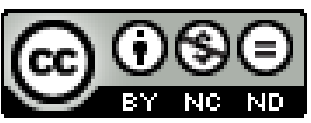


Established and emerging factors affecting the progression of nonalcoholic fatty liver disease

Stergios Kechagias ${ }^{1}$, Patrik Nasr ${ }^{1}$, Julia Blomdahl ${ }^{1}$, Mattias Ekstedt ${ }^{1}$

${ }^{1}$ Department of Gastroenterology and Hepatology, Department of Medical and Health Sciences, Linköping University, Linköping, Sweden

stergios.kechagias@liu.se, patrik.nasr@liu.se, julia.blomdahl@liu.se, mattias.ekstedt@liu.se

\section{Corresponding author:}

Stergios Kechagias

Department of Gastroenterology and Hepatology

University Hospital, SE-581 85 Linköping, Sweden

stergios.kechagias@liu.se

Word count (excluding title page, abstract, references, tables, figure legends): 4,560 References: 175 Tables: 2 Figures: 2 
List of abbreviations: AAT, alpha- 1 antitrypsin; AATD, alpha-1 antitrypsin deficiency; AST, aspartate aminotransferase; BMI, body mass index; CVD, cardiovascular disease; DIOS, dysmetabolic iron overload syndrome; DNL, de novo lipogenesis; FFA, free fatty acid; FIB-4, Fibrosis-4; FS, fibrosis stage; GCKR, glucokinase regulatory protein; GWAS, genome-wide association studies; HCC, hepatocellular carcinoma; HDL, high-density lipoprotein; HSD17B13, 17ß-hydroxysteroid dehydrogenase 13; IL-6, interleukin-6; IL-28B, interleukin28B; JAK-STAT, janus kinase-signal transducer and activator of transcription proteins; JNK, c-Jun $\mathrm{NH}_{2}$-terminal kinase; KLF6, Kruppel-like factor 6; LDL, low-density lipoprotein; LYPLAL1, lysophospholipase like 1; MARC1, mitochondrial amidoxime-reducing component 1; MBOAT7, membrane bound O-acyltransferase domain-containing 7; MCP-1, monocyte chemoattractant protein-1; MERTK, MER protocol-oncogene, tyrosine kinase; MRI, magnetic resonance imaging; NAFL, NAFLD, nonalcoholic fatty liver disease; NASH, nonalcoholic

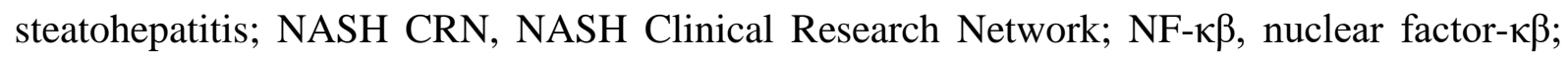
PEth, phosphatidylethanol; Pi, proteinase inhibitor; PNPLA3, patatin-like phospholipase domain-containing 3; ROS, reactive oxygen species; SERPINA1, serine proteinase inhibitor 1; SNP, single-nucleotide polymorphism; T2DM, type 2 diabetes mellitus; TM6SF2, transmembrane 6 superfamily 2; TG, triglycerides; TNF- $\alpha$, tumor necrosis factor- $\alpha$; UCP2, uncoupling protein 2; VLDL, very low-density lipoprotein. 


\begin{abstract}
Non-alcoholic fatty liver disease (NAFLD) has become the most common chronic liver disease affecting approximately $25 \%$ of the global population. Although a majority of NAFLD patients will never experience liver-related symptoms it is estimated that $5-10 \%$ will develop cirrhosisrelated complications with risk of death or need for liver transplantation. NAFLD is closely associated with cardiovascular disease and components of the metabolic syndrome. However, NAFLD is not uncommon in lean individuals and may in these subjects represent a different entity with separate pathophysiological mechanisms involved implying a higher risk for development of end-stage liver disease. There is considerable fluctuation in the histopathological course of NAFLD that may partly be attributed to lifestyle factors and dietary composition. Nutrients such as fructose, monounsaturated fatty acids, and trans-fatty acids may aggravate NAFLD. Presence of type 2 diabetes mellitus seems to be the most important clinical predictor of liver-related morbidity and mortality in NAFLD. Apart from severity of the metabolic syndrome, genetic polymorphisms and environmental factors, such as moderate alcohol consumption, may explain the variation in histopathological and clinical outcome among NAFLD patients.
\end{abstract}

Keywords: End-stage liver disease, Liver-related complications, Hepatocellular carcinoma, Fibrosis progression 


\section{Introduction}

Accumulation of lipids (steatosis) is the most common histopathologic hepatic alteration/finding globally. Hepatic triglyceride content can be accurately measured noninvasively with magnetic resonance imaging (MRI) [1,2]. Using a cut-off of $5.56 \%$ the prevalence of fatty liver among 2,287 individuals included in the Dallas Heart Study was 31\% [3] and the global prevalence has been estimated to 25\% [4]. However, recently it was shown that more subjects with biopsy-proven steatosis could be diagnosed with MRI using a cut-off of 3\% [5] which implies that the prevalence of fatty liver has probably been underestimated in previous studies.

In most individuals with hepatic steatosis the underlying cause is alcohol overconsumption or nonalcoholic fatty liver disease (NAFLD) [6]. NAFLD is considered the hepatic manifestation of the metabolic syndrome [7]. Initially NAFLD was considered a benign disease but these days the progressive potential of NAFLD is indisputable with $5-10 \%$ of subjects progressing to cirrhosis, end-stage liver disease or hepatocellular carcinoma (HCC) [8]. Although the vast majority of NAFLD patients will never experience liver-related complications the high prevalence of NAFLD entails a significant public health issue with a high disease and economic burden and an increased need of liver transplantation [4].

NAFLD entails a spectrum of histopathological features that ranges from simple steatosis via establishment of inflammation and hepatocellular injury, i.e. non-alcoholic steatohepatitis (NASH), with or without fibrosis to cirrhosis with risk for development of end-stage liver disease or HCC [9-10]. An overview of the putative mechanisms involved in progression of NAFLD is shown in Fig. 1.

NAFLD is independently associated with cardiovascular disease (CVD) and type 2 diabetes mellitus (T2DM) [11-14]. Moreover, there is a collinearity between the severity of NAFLD and the components of the metabolic syndrome [15-17]. There is considerable fluctuation (i.e. 
progression and regression) of inflammation and fibrosis in NAFLD [18-19]. Particularly inflammation is highly dynamic, partly attributed to lifestyle factors that are difficult to completely account and control for in clinical trials. These include weight change, dietary composition and alcohol consumption. Although inflammation and hepatocellular injury, i.e. $\mathrm{NASH}$, is considered a progressive form of NAFLD, follow-up studies have shown that hepatic fibrosis is the only independent predictor of clinical disease progression. There are 14 studies with paired biopsies in NAFLD [20-33], including in total 996 patients with a median follow-up time ranging from 1.8 to 13.8 years (Table 1 ). Whether NASH precedes fibrosis in NAFLD is disputed. NASH correlates with presence of fibrosis, but this does not mean that NASH equals the prediction of fibrosis progression. To date, there is no objective evidence that presence of NASH at baseline, correlates with progression of fibrosis.

NAFLD patients with advanced fibrosis, as defined by stage 3-4 fibrosis, are at the highest risk of developing cirrhosis-related complications which may lead to liver transplantation or death [34-36]. The presence of advanced fibrosis, particularly cirrhosis, alters clinical management, including the possible initiation of surveillance for gastroesophageal varices and HCC, and consideration for treatment, including in the context of clinical trials. The burden of advanced fibrosis caused by NAFLD is projected to further increase in coming decades because of the rising prevalence of obesity [37]. Thus, this review will primarily focus on factors that have been shown to be associated with advanced fibrosis and/or affect fibrosis progression and the development of cirrhosis, end-stage liver disease, liver-related, and allcause mortality in NAFLD (Fig. 2).

\section{Body mass index (BMI) and weight change}

\subsection{Obesity}


Overweight and obesity increases the risk of incident NAFLD substantially. The prevalence of NAFLD increases exponentially with higher BMI and reaches $57 \%$ in men and $44 \%$ in women with BMI $>35 \mathrm{~kg} / \mathrm{m}^{2}$ when ultrasonography is used as diagnostic tool [38]. However, the sensitivity of ultrasonography is poor in low grade steatosis and thus the prevalence of NAFLD is probably even higher among obese subjects. Weight gain during young adulthood has been linked to future development of NAFLD [39\}. Furthermore, weight loss, either by lifestyle intervention or bariatric surgery, is associated with resolution of NAFLD as well as insulin resistance [40-44]. In more pronounced weight loss $(\geq 10 \%)$ not only steatosis is reduced but also inflammation and fibrosis are positively affected [45].

Obesity and visceral adiposity predict development of severe liver disease in the general population [46-48]. In a prospective study by Calle et al, an exponential increase in the risk of HCC for every 5 unit increase in BMI was evident in males [49]. Similar findings were reported by Hagström et al, who studied 1.2 million men enlisted for military conscription in Sweden [50]. Subjects were followed for a mean period of 28.5 years and at the end of follow-up, 5,281 cases of severe liver disease and 251 cases of HCC were identified. Individuals who were overweight or obese at baseline had an increased hazard ratio for HCC of 1.68 (95\%CI 1.092.57) and 4.28 (95\%CI 2.25-8.15), respectively.

\subsection{Lean NAFLD}

Although most NAFLD patients have a BMI of $\geq 25 \mathrm{~kg} / \mathrm{m}^{2}$, a subset of individuals has a BMI $<25 \mathrm{~kg} / \mathrm{m}^{2}$, which is usually denoted as lean NAFLD [51]. The prevalence of lean NAFLD ranges from 12 to $20 \%$ in different populations [52-57]. Lean NAFLD is more common in Asia (India [52], Japan [53], China [54], Korea [56]), but it has recently been recognized as an important clinical entity also among Caucasians (Greece [55], USA [57], Australia [58], Sweden [59]). A significant proportion of lean NAFLD patients are individuals manifesting 
the disease with normal BMI but having excess visceral adiposity and insulin resistance. However, accumulating evidence suggests that lean NAFLD in many subjects represents a distinct pathophysiological entity with the onset of disease occurring at a lower BMI with lower levels of insulin resistance and is influenced by genetic factors, alterations in gut microbiota, and bile acids [4,58]. In a recent follow-up study [59] it was shown that lean NAFLD patients had higher risk of future development of severe liver disease compared to NAFLD patients with a BMI of $\geq 25 \mathrm{~kg} / \mathrm{m}^{2}$. This occurred despite the finding that lean NAFLD patients had lower prevalence of advanced fibrosis and NASH at baseline. This suggests that fibrosis progression is faster in lean NAFLD. Genetic variations, differences in dietary patterns and other lifestyle parameters that may affect fibrosis progression could possibly explain the association between lean NAFLD and the increased risk of future development of severe liver disease. Further studies are needed to elucidate these aspects.

\subsection{NAFLD and weight: Summary}

In summary, obesity increases the risk of NAFLD. Although there is a statistically significant increased risk for development of future end-stage liver disease including HCC, most obese subjects with NAFLD will not experience liver-related morbidity. Modest weight reduction $(\geq 5 \%)$ reduces steatosis but in order to stabilize or reduce fibrosis stage, the only histopathological feature associated with long-term outcomes of patients with NAFLD, more profound weight reduction $(\geq 10 \%)$ seems to be necessary. NAFLD in lean subjects may represent a different entity with separate pathophysiological mechanisms involved implying a higher risk for development of end-stage liver disease.

\section{Physical activity}

Increasing physical activity reduces intrahepatic triglyceride content and markers of hepatocellular injury in NAFLD patients independently of weight loss. However, there are 
insufficient data supporting the effects of physical activity on the progression of NAFLD to

NASH with advanced fibrosis, and on extrahepatic disease-related morbidity and mortality. [60-64].

\section{Type 2 diabetes (T2DM)}

\subsection{Type 2 diabetes and NAFLD}

Since 1980 the age-standardized prevalence of T2DM in adults has increased substantially [65]. Among the components of the metabolic syndrome, T2DM seems to be the most important risk factor for having NAFLD (including NASH) and the most important clinical predictor of liver-related morbidity and mortality [66-70]. NAFLD is highly intertwined with T2DM, showing a bidirectional interaction [17, 71-74] but whether NAFLD precedes or succeeds T2DM has not been clarified [75-76].

The prevalence of T2DM in NAFLD patients ranges from $45 \%$ to $75 \%$ in hospital-based studies and from $30 \%$ to $60 \%$ in population-based studies [77]. In a recently published metaanalysis, the global prevalence of NAFLD among patients with T2DM was estimated to 55\%, while the European prevalence was even higher (68\%). The global prevalence of NASH among individuals with T2DM was 37\%, while the prevalence of advanced fibrosis in patients with NAFLD and T2DM was 17\% [78]. Moreover, other reports indicate the additive risk of both NASH and T2DM, resulting in a worse metabolic profile and a higher risk of CVD [79-80].

In a systematic review and meta-analysis by Bellestri et al, a twofold increase in the risk of incident T2DM was reported in NAFLD patients [81]. Similar results were reported by Chen et al [82]. The relationship between biopsy-proven NAFLD and the future risk of developing T2DM has also been studied. In a long-term follow-up study [29] of 129 NAFLD patients 8.5\% had T2DM at baseline. After a mean follow-up time of 13.7 years, 53\% was diagnosed with 
T2DM or impaired glucose tolerance. In an extended follow-up of the same cohort, $71 \%$ was diagnosed with T2DM or impaired glucose tolerance after a mean follow-up of 19.8 years [8]. McPherson et al. also showed association between NAFLD and future development of T2DM [83]. At baseline the prevalence of T2DM was $48 \%$, which increased to $65 \%$ after a median follow-up of 6.6 years.

Hitherto 14 dual biopsy studies have been conducted in NAFLD patients with an overall T2DM prevalence of 43\% (Table 1) [20-33]. In these studies, presence of T2DM did not predict fibrosis progression. Nevertheless, overall mortality [34,68] and liver-related morbidity [68] are increased in patients with NAFLD and concomitant T2DM. Moreover, patients with T2DM seem to have an increased mortality in the presence of concomitant NAFLD [84].

In a retrospective study including 148 subjects undergoing liver biopsy, diabetes was more prevalent in patients with liver-related clinical outcomes compared to patients without endstage liver disease (62.5\% vs. 27.4\%) [85]. Moreover, in a recent study by Vilar-Gomez et al, T2DM was shown to be a strong negative predictor of transplantation free survival (HR 3.33, 95\%CI 1.69-6.54) and liver-related outcomes (sHR 2.82, 95\%CI $1.54-5.15$ for decompensation and sHR 4.72, 95\%CI 2.13-10.45 for HCC) [86].

\subsection{Type 2 diabetes and hepatocellular carcinoma (HCC)}

The relationship between T2DM and HCC is well established [87-89]. Patients with T2DM, without viral hepatitis or alcohol overconsumption, have a twofold increased risk of developing HCC compared to patients without diabetes (aHR 2.13, 95\%CI 1.99-2.28) [90]. Moreover, T2DM seems to be an independent risk factor for developing HCC, mainly attributed to NAFLD [90-91]. Dyson et al reported a 1.8-fold increase in mortality from HCC between 2000 and 2010. This was mainly attributed to increasing prevalence of NAFLD, which nowadays is the most common chronic liver disease associated with HCC [92]. 
The collinearity between NAFLD and T2DM is high and therefore it is hard to assess if the increased risk of HCC is secondary to T2DM itself, or its hepatic manifestation (i.e. NAFLD). Therefore, more studies are needed depicting whether NAFLD patients with T2DM have an increased risk of HCC compared to NAFLD patients without T2DM.

\section{Hypertension}

In a meta-analysis [93] of 11 cohort studies (411 patients) assessing paired liver biopsy specimens to estimate the rates of fibrosis progression in NAFLD patients it was found that the presence of hypertension (odds ratio, 1.94; 95\% CI, 1.00-3.74) at the time of baseline biopsy was associated with the development of progressive fibrosis.

\section{Dyslipidemia}

Hypertriglyceridemia is common in NAFLD patients [94]. Increased non-HDL cholesterol levels are associated with NASH, which correlates with presence of fibrosis and is likely to impact on risk of developing future end-stage liver disease [95-96]. However, when cirrhosis develops due to NAFLD the severity of the initial hyperlipidemia is often blunted because of hepatic biosynthetic failure [97-99], which parallels the disappearance of hepatic steatosis in NASH cirrhosis [100].

\section{Sarcopenia}

The strongest evidence to prove an independent association of NAFLD with sarcopenia, i.e, the loss of muscle mass and/or strength, was given in a study from Korea [101], in which this association was investigated in a large cohort of both obese and non-obese subjects ( $n=$ 15,132). A strong inverse relationship of the skeletal muscle index, a measure for muscle mass, with NAFLD was found. Accordingly, the prevalence of NAFLD in sarcopenic subjects 
was higher compared to non-sarcopenic subjects, irrespective of the presence of obesity or the metabolic syndrome. Studies evaluating the association of fibrosis in NAFLD with sarcopenia have found a significant relationship between fibrosis and sarcopenia [101-106], regardless if significant fibrosis was defined non-invasively or based on biopsy. However, most studies assessing sarcopenia in NAFLD included mainly Asian patients. Hence, extrapolating these results to other than Asian groups may be problematic because of differences in body composition between ethnicities.

\section{Age}

Cross-sectional studies have demonstrated increasing age to be associated with more severe fibrosis in NAFLD. However, this may reflect the cumulative sum of metabolic exposures and longer duration of the disease in these populations [67, 107-108]. In contrast, longitudinal studies have not consistently demonstrated age to impact the rate of fibrosis progression [93].

\section{Alcohol}

Alcohol overconsumption is the leading cause of end-stage liver disease in the Western world [109]. A putative crucial factor for the course of NAFLD is the impact of the quantity, pattern, and duration of alcohol consumption. Weekly alcohol consumption in excess of $210 \mathrm{~g}$ for men and $140 \mathrm{~g}$ for women is not compatible with diagnosis of NAFLD and excludes subjects from NAFLD research studies [110]. However, these arbitrary thresholds are based on levels above which the risk of cirrhosis is higher and have not been specifically shown to influence NAFLD [111]. On the other hand, the most common cause of mortality and morbidity in NAFLD patients is CVD [29,112] and NAFLD and CVD share many common risk factors. There is evidence for beneficial effects of modest alcohol consumption on risk of metabolic syndrome and insulin resistance [113], which are crucial factors of the NAFLD disease process. 


\subsection{Moderate alcohol consumption: The evidence for protection}

A meta-analysis of mostly cross-sectional studies concluded that moderate alcohol consumption was associated with a $23 \%$ reduction in the prevalence of fatty liver disease [114]. In a prospective Japanese study of subjects without liver disease at baseline alcohol consumption was associated with decreased incidence of steatosis [115]. Moreover, moderate alcohol consumption did not induce fatty liver in healthy individuals when hepatic triglyceride content was measured prospectively with proton magnetic resonance spectroscopy in a randomized study [116].

In a cross-sectional study of adult patients with biopsy-proven NAFLD, after exclusion of heavy and binge drinkers, modest alcohol consumption was associated with 34\% less hepatocellular ballooning and 44\% lower risk of liver fibrosis compared with nondrinkers [117]. Similar results were shown in a Swedish study of 120 NAFLD patients with biopsy-proven NAFLD in which a maximum of 13 drinks per week was associated with lower fibrosis stage [118]. However, increased levels of phosphatidylethanol (PEth) in blood were associated with higher stages of fibrosis. This may indicate that more pronounced alcohol consumption, contrary to modest consumption, is harmful in NAFLD or that assessment of alcohol consumption through questionnaires is prone to error.

Currently, twelve studies have assessed the impact of alcohol on histopathology in NAFLD (Table 2) [117-128]. Robust conclusions cannot be drawn since study design varies and particularly since the definition of moderate alcohol consumption is not consistent. However, type of alcohol and pattern of consumption seem to affect the histopathological course of NAFLD. Generally, consumption of moderate amounts of alcohol ( $<70$ g/week) is associated with a lower rate of NASH and fibrosis, especially if wine is consumed in a non-binge pattern. 
Results regarding the effect of alcohol consumption on survival in NAFLD patients have been conflicting [115,117]. Recently, 4,568 subjects with NAFLD from the National Health and Nutrition Examination Survey were evaluated. Consumption of 7 g to $21 \mathrm{~g}$ alcohol per day decreased the risk of overall mortality by $41 \%$ compared with not drinking [129]. Since NAFLD patients are more likely to die from CVD than liver disease these results are in accordance with previous studies showing that modest alcohol consumption is associated with decreased risk of cardiovascular disease mortality [130]. However, a major weakness of the aforementioned study [129] is that the diagnosis of NAFLD was based on a biochemical model and not on imaging or histology.

\subsection{Moderate alcohol consumption: The evidence for detrimental effects}

In some studies, moderate alcohol consumption is associated with a more advanced histopathological stage. Binge drinking (occasional consumption of $>60 \mathrm{~g}$ ethanol in males and $>48 \mathrm{~g}$ in females) may be harmful since it is associated with higher fibrosis stages. In a histopathological study from Sweden, 71 NAFLD patients were followed for an average of almost 14 years and it was shown that heavy episodic drinking was associated with increased risk of progression of fibrosis [119]. Further evidence for a potentially harmful effect of moderate alcohol consumption on the progression of NAFLD comes from a recently published longitudinal study, in which it was concluded that NAFLD patients with moderate alcohol consumption were less likely to experience spontaneous improvement in liver histology [120].

The largest study assessing the effect of alcohol on the severity of NAFLD was recently reported by Chang et al [131]. They studied the effect of moderate alcohol consumption on non-invasive liver fibrosis indices in 58,927 Korean adults with NAFLD and low fibrosis scores who were followed for a median of 8.3 years. The authors concluded that moderate alcohol consumption was associated with deterioration of non-invasive markers of fibrosis. Fibrosis stage is the best predictor of future liver-related morbidity and overall mortality in NAFLD [34- 
36]. Thus, their study may indicate that modest alcohol consumption is harmful in subjects with NAFLD. However, a major weakness of using non-invasive fibrosis markers is that, although they are excellent in ruling out significant fibrosis, their ability to confirm advanced fibrosis is limited when liver biopsy is used as the reference method. Thus, worsening of fibrosis indices does not necessarily imply that liver fibrosis has progressed during follow-up.

Increasing evidence suggests an additive, or even a synergistic, effect between alcohol consumption and BMI for the development of HCC [132]. In a recent Japanese study of 301 patients with biopsy-proven NAFLD, patients with modest drinking had significantly higher risk of developing HCC compared with nondrinkers [121].

\subsection{NAFLD and alcohol: Summary}

In summary, most studies indicate that modest alcohol consumption is associated with decreased risk for development of fatty liver disease and moderate drinking may be associated with increased survival in NAFLD patients. Emerging evidence indicates an additive risk of BMI and alcohol for the development of HCC in NAFLD. There are conflicting results regarding the role of alcohol for fibrosis progression in established NAFLD. Further studies are needed before well-grounded advice can be given to NAFLD patients regarding modest alcohol consumption.

\section{Genetics}

\subsection{Genome-wide association studies}

Genome-wide association studies (GWAS) have identified numerous gene loci associated with NAFLD. The two most extensively studied polymorphisms are the patatin-like phospholipase domain-containing 3 (PNPLA3) and the transmembrane 6 superfamily 2 (TM6SF2). PNPLA3 codes for adiponutrin, a protein involved in lipid remodeling, and the gene product of TM6SF2 is involved in VLDL secretion from hepatocytes. Both genes have in several studies been associated 
with hepatic steatosis, NASH and advanced fibrosis [133-136]. Moreover, the rs738409 c.444 C>G, p.lle148Met polymorphism in the PNPLA3 gene has been associated with increased risk for development of HCC in NAFLD [137-139].

The gene locus rs641738 at the membrane bound O-acyltransferase domain-containing 7 (MBOAT7) has also been associated with NAFLD [140], but this association has recently been questioned [141]. In some studies, the genes lysophospholipase like 1 (LYPLAL1), glucokinase regulatory protein (GCKR), and PP1R3B have been associated with NAFLD but further confirmatory studies are needed [142-143].

Interestingly, several genes protective of hepatic steatosis and fibrosis have recently been reported, the mitochondrial amidoxime-reducing component 1 (MARC1), the 17 $\beta$ hydroxysteroid dehydrogenase 13 (HSD17B13), the LPIN1, the uncoupling protein 2 (UCP2), the interleukin-28B (IL-28B), the Kruppel-like factor 6 (KLF6), and the MER protocoloncogene, tyrosine kinase (MERTK) [144].

\subsection{HFE, ferritin, and iron}

The dysmetabolic iron overload syndrome (DIOS), which corresponds to a mild increase of hepatic and total body iron content, is a common finding among subjects with the metabolic syndrome and NAFLD. The pathogenesis of DIOS is related to altered regulation of iron transport associated with steatosis, insulin resistance, and subclinical inflammation, often in the presence of predisposing genetic factors. Hyperferritinemia has been reported in 58\% [145] and approximately one third of NAFLD patients have stainable hepatic iron [146-147]. However, in many NAFLD patients elevated ferritin reflects subclinical inflammatory state, not iron overload. Thus, association between hyperferritinemia and severity of NAFLD may not reflect detrimental effects of iron in NAFLD. 
The relationship of serum ferritin with severity of NAFLD has been examined in several studies [148-151]. In a study by the NASH Clinical Research Network (NASH CRN), 628 patients with biopsy-proven NAFLD were included [151]. Patients with a ferritin higher than 1.5 times and 2.5 times the upper limit of normal had a 1.67 and 2.46-fold increased risk of advanced fibrosis, respectively. Moreover, Hagström et al showed that patients with biopsy-proven NAFLD with higher levels of ferritin had a long-term increased risk of death [152]. Although the association between ferritin and advanced fibrosis has been corroborated by several study groups [150-151,153], the use of ferritin for predicting presence of advanced fibrosis in NAFLD is low [153].

In a study by Valenti et al, 587 biopsy-proven NAFLD patients were enrolled to investigate the effects of iron and HFE in NAFLD [154]. They reported that hepatocellular iron accumulation was associated with a higher risk of fibrosis stage $>1$ (aOR 1.7, 95\%CI 1.2-2.3) compared to patients without histopathological siderosis. Although, there was no significant association between presence of specific HFE genotypes and the severity of fibrosis, one third of patients with HFE mutations had hepatocellular iron deposits.

Early case studies of iron depletion through phlebotomy showed decreased insulin resistance [155], reduction of steatosis [156], and liver enzymes in serum [156-157]. However, in a phase 2 clinical trial [158] and a randomized controlled trial [159], phlebotomy had no effect on liver enzymes, hepatic triglyceride content, insulin resistance or histopathological features of NAFLD. However, none of the studies evaluated fibrosis progression and end-stage liver disease as endpoints.

\subsection{Alpha-1 antitrypsin deficiency}

Alpha-1 antitrypsin deficiency (AATD) caused by mutations in the gene serine proteinase inhibitor 1 (SERPINA1) previously known as proteinase inhibitor (Pi) is most common in 
Scandinavia and North America. In a meta-analysis by Serres et al, the global prevalence for heterozygotic SERPINA1 mutations (MS and MZ) was 3.4\% and for homozygotic mutations (ZZ, ZS and SS) $0.8 \%$ [160].

While the presence of the $\mathrm{ZZ}$ genotype portends a high risk of future liver disease, the role of MZ in liver disease remains controversial [161-162]. In a study by Regev et al, 651 patients with known chronic liver disease, of whom 26\% had NAFLD, were tested for alpha-1 antitrypsin (AAT) phenotypes [163]. Although they did not find any association between heterozygous Z state and the presence of chronic liver disease, the presence of the MZ state was more common in NAFLD patients with decompensated liver disease. Strnad et al. included 1,148 patients with biopsy proven NAFLD [164]. Of patients with cirrhosis, 13.8\% had the Z variant present, compared to $2.4 \%$ of those without fibrosis. The $\mathrm{Z}$ variant was associated with increased risk for cirrhosis (aOR 7.3, 95\%CI 2.2-24.8). These studies may indicate that the MZ state is a risk factor for progression of fibrosis in NAFLD but further confirmatory studies are needed.

\section{Nutrients}

In subjects with the metabolic syndrome excessive dietary carbohydrate and fat intake have been associated with the occurrence of insulin resistance as well as NAFLD [165-167]. Carbohydrates are important stimuli of hepatic de novo lipogenesis and are more likely to directly contribute to NAFLD than dietary fat [168]. Especially fructose has been linked as a major substrate for de novo hepatic lipogenesis and fibrosis [169]. Sugar-sweetened beverages increased liver and visceral fat over a 6-month period as compared to milk and water [170]. Moreover, fructose has been associated with increased oxidative stress in the liver [171].

A higher dietary lipid intake with a higher omega-6 to omega-3 polyunsaturated fatty acids ratio and a higher intake of saturated fat have also been associated with hepatic inflammation and NAFLD [172]. Thus, an increase in the intake of monounsaturated fatty acids may modify the 
progression of NAFLD. Furthermore, trans-fatty acids are implicated in the metabolic syndrome, as they are strongly associated with an increase in hepatic inflammatory processes, cholesterol, and plasma triglycerides, as well as a reduction in HDL cholesterol [173]. A previous animal study demonstrated the presence of a positive correlation between the increased intake of trans-fatty acids from oxidized oils and hepatic inflammation [173].

The importance of dietary vitamin intake and decreased hepatic triglyceride content have been addressed in several studies. One of these studies assessed the role of vitamin A in the pathogenesis of NAFLD [174]. It was shown that hepatic steatosis may be reduced by retinoic acid. Another study by Kwok et al. [175], reported that NAFLD patients had lower serum levels of vitamin D, suggesting that vitamin D deficiency may play a role in the pathogenesis of NAFLD.

\section{Conclusions}

NAFLD is present in approximately $25 \%$ of the population globally. The natural history and impact on patient morbidity and mortality is widely divergent. Presence of high age, metabolic factors, such as T2DM, obesity, and hypertension, influence the severity of underlying liver histology and, thus, are likely to impact on risk of developing cirrhosis and HCC. Recent studies have emphasized the importance of fibrosis stage in determining future mortality risk. NAFLD patients with the aforementioned risk factors should undergo assessment with at first hand non-invasive methods and, in case of indeterminant results, liver biopsy in order to evaluate severity of fibrosis. Genetic polymorphisms, particularly in the PNPLA3 and TM6SF2 genes, influence severity of NAFLD and may be implemented in the diagnostic work-up of NAFLD patients in the future. Lifestyle factors, such as dietary composition and moderate alcohol consumption, may also influence the progression of NAFLD. However, further studies are needed before solid lifestyle advice can be given to patients. 
Funding: This research did not receive any specific grant from funding agencies in the public, commercial, or not-for-profit sectors

Potential competing interests: The authors have no competing interests to declare 


\section{References}

[1] Reeder SB, Sirlin CB. Quantification of liver fat with magnetic resonance imaging. Magn Reson Imaging Clin N Am 2010;18:337-57.

[2] Reeder SB, Cruite I, Hamilton G, Sirlin CB. Quantitative assessment of liver fat with magnetic resonance imaging and spectroscopy. J Magn Reson Imaging 2011;34:729-49.

[3] Browning JD, Szczepaniak LS, Dobbins R, Nuremberg P, Horton JD, Cohen JC, et al. Prevalence of hepatic steatosis in an urban population in the United States: impact of ethnicity. Hepatology 2004;40:1387-95.

[4] Younossi ZM, Koenig AB, Abdelatif D, Fazel Y, Henry L, Wymer M. Global epidemiology of nonalcoholic fatty liver disease - Meta-analytic assessment of prevalence, incidence, and outcomes. Hepatology 2016;64:73-84.

[5] Nasr P, Forsgren MF, Ignatova S, Dahlström N, Cedersund G, Dahlqvist Leinhard O, et al. Using a 3\% proton density fat fraction as a cut-off value increases sensitivity of detection of hepatic steatosis, based on results from histopathology analysis. Gastroenterology 2017;153;535.e7.

[6] Younossi ZM, Stepanova M, Afendy M, Fang Y, Younossi Y, Mir H, et al. Changes in the prevalence of the most common causes of chronic liver diseases in the United States from 1988 to 2008. Clin Gastroenterol Hepatol 2011;9:524-30.e1; quiz e60.

[7] Marchesini G, Brizi M, Bianchi G, Tomassetti S, Bugianesi E, Lenzi M, et al. Nonalcoholic fatty liver disease: a feature of the metabolic syndrome. Diabetes 2001;50:1844-50.

[8] Nasr P, Ignatova S, Kechagias S, Ekstedt M. Natural history of nonalcoholic fatty liver disease: a prospective follow-up study with serial biopsies. Hepatol Commun 2017;2:199-210. 
[9] Matteoni CA, Younossi ZM, Gramlich T, Boparai N, Liu YC, McCullough AJ, et al. Nonalcoholic fatty liver disease: a spectrum of clinical and pathological severity. Gastroenterology 1999;116:1413-9.

[10] Sanyal AJ, Association AG. AGA technical review on nonalcoholic fatty liver disease. Gastroenterology 2002;123:1705-25.

[11] Wu S, Wu F, Ding Y, Hou J, Bi J, Zhang Z, et al. Association of non-alcoholic fatty liver disease with major adverse cardiovascular events: a systematic review and meta-analysis. Sci Rep 2016;6:33386.

[12] Targher G, Day CP, Bonora E. Risk of cardiovascular disease in patients with nonalcoholic fatty liver disease. N Engl J Med 2010;363:1341-50.

[13] Targher G, Byrne CD, Lonardo A, Zoppini G, Barbui C. Non-alcoholic fatty liver disease and risk of incident cardiovascular disease: a meta-analysis. J Hepatol 2016;65:589-600.

[14] Fracanzani AL, Tiraboschi S, Pisano G, Consonni D, Baragetti A, Bertelli C, et al. Progression of carotid vascular damage and cardiovascular events in non-alcoholic fatty liver disease patients compared to the general population during 10 years of follow-up. Atherosclerosis 2016;246:208-13.

[15] Byrne CD, Targher G. NAFLD: A multisystem disease. J Hepatol 2015;62:S47-S64.

[16] Byrne CD, Olufadi R, Bruce KD, Cagampang FR, Ahmed MH. Metabolic disturbances in non-alcoholic fatty liver disease. Clinical Sci (Lond) 2009;116:539-64.

[17] Yki-Järvinen H. Non-alcoholic fatty liver disease as a cause and a consequence of metabolic syndrome. Lancet Diabetes Endocrinol 2014;2:901-10. 
[18] Friedman SL, Ratziu V, Harrison SA, Abdelmalek MF, Aithal GP, Caballeria J, et al. A randomized, placebo-controlled trial of cenicriviroc for treatment of nonalcoholic steatohepatitis with fibrosis. Hepatology 2018;67:1754-67.

[19] Schuppan D, Surabattula R, Wang XY. Determinants of fibrosis progression and regression in NASH. J Hepatol 2018;68:238-50.

[20] Lee RG. Nonalcoholic steatohepatitis: a study of 49 patients. Hum Pathol 1989;20:594-8.

[21] Powell EE, Cooksley WG, Hanson R, Searle J, Halliday JW, Powell LW. The natural history of nonalcoholic steatohepatitis: a follow-up study of forty-two patients for up to 21 years. Hepatology 1990;11:74-80.

[22] Teli MR, James OF, Burt AD, Bennett MK, Day CP. The natural history of nonalcoholic fatty liver: a follow-up study. Hepatology 1995;22:1714-9.

[23] Ratziu V, Giral P, Charlotte F, Bruckert E, Thibault V, Theodorou I, et al. Liver fibrosis in overweight patients. Gastroenterology 2000;118:1117-23.

[24] Evans CD, Oien KA, MacSween RN, Millis PR. Non-alcoholic steatohepatitis: a common cause of progressive chronic liver injury? J Clin Pathol 2002;55:689-92.

[25] Harrison SA, Torgerson S, Hayashi PH. The natural history of nonalcoholic fatty liver disease: a clinical histopathological study. Am J Gastroenterol 2003;98:2042-7.

[26] Fassio E, Alvarez E, Domínguez N, Landeira G, Longo C. Natural history of nonalcoholic steatohepatitis: a longitudinal study of repeat liver biopsies. Hepatology 2004;40:820-6.

[27] Adams LA, Sanderson S, Lindor KD, Angulo P. The histological course of nonalcoholic fatty liver disease: a longitudinal study of 103 patients with sequential liver biopsies. J Hepatol 2005;42:132-8. 
[28] Hui AY, Wong VW, Chan HL, Liew CT, Chan JL, Chan FK, et al. Histological progression of non-alcoholic fatty liver disease in Chinese patients. Aliment Pharmacol Ther 2005;21:40713.

[29] Ekstedt M, Franzén LE, Mathiesen UL, Thorelius L, Holmqvist M, Bodemar G, et al. Long-term follow-up of patients with NAFLD and elevated liver enzymes. Hepatology 2006;44:865-73.

[30] Wong VW, Wong GL, Choi PC, Chan AW, Li MK, Chan HY, et al. Disease progression of non-alcoholic fatty liver disease: a prospective study with paired liver biopsies at 3 years. Gut 2010;59:969-74.

[31] Pais R, Charlotte F, Fedchuk L, Bedossa P, Lebray P, Poynard T, et al. A systematic review of follow-up biopsies reveals disease progression in patients with non-alcoholic fatty liver. $\mathrm{J}$ Hepatol 2013;59:550-6.

[32] McPherson S, Hardy T, Henderson E, Burt AD, Day CP, Anstee QM et al. Evidence of NAFLD progression from steatosis to fibrosing-steatohepatitis using paired biopsies: Implications for prognosis and clinical management. J Hepatol 2015:62;1148-55.

[33] Sanyal AJ, Harrison SA, Ratziu V, Abdelmalek MF, Diehl AM, Caldwell S, et al. The natural history of advanced fibrosis due to nonalcoholic steatohepatitis: Data from the simtuzumab trials. Hepatology 2019;70:1913-27.

[34] Angulo P, Kleiner DE, Dam-Larsen S, Adams LA, Björnsson EA, Charatcharoenwitthaya P, et al. Liver fibrosis, but no other histologic features, is associated with long-term outcomes of patients with nonalcoholic fatty liver disease. Gastroenterology 2015;149:389-97.e10. 
[35] Ekstedt M, Hagström H, Nasr P, Fredrikson M, Stål P, Kechagias S, et al. Fibrosis stage is the strongest predictor for disease-specific mortality in NAFLD after up to 33 years of followup. Hepatology 2015;61:1547-54.

[36] Hagström H, Nasr P, Ekstedt M, Hammar U, Stål P, Hultcramtz R, et al. Fibrosis stage but not NASH predicts mortality and time to development of severe liver disease in biopsy-proven NAFLD. J Hepatol 2017;67:1265-73.

[37] Estes C, Razavi H, Loomba R, Younossi Z, Sanyal AJ. Modeling the epidemic of nonalcoholic fatty liver disease demonstrates an exponential increase in burden of disease. Hepatology 2018;67:123-33.

[38] Lazo M, Hernaez R, Eberhardt MS, Bonekamp S, Kamel I, Guallar E, et al. Prevalence of nonalcoholic fatty liver disease in the United States: the Third National Health and Nutrition Examination Survey, 1988-1994. Am J Epidemiol 2013;178:38-45.

[39] VanWagner LB, Khan SS, Ning H, Siddique J, Lewis CE, Carr JJ, et al. Body mass index trajectories in young adulthood predict non-alcoholic fatty liver disease in middle age: The CARDIA cohort study. Liver Int 2018;38:706-14.

[40] Centis E, Marzocchi R, Di Domizio S, Ciaravella MF, Marchesini G, et al. The effect of lifestyle changes in non-alcoholic fatty liver disease. Dig Dis 2010;28:267-73.

[41] Zelber-Sagi S, Lotan R, Shlomai A, Webb M, Harrari G, Buch A, et al. Predictors for incidence and remission of NAFLD in the general population during a seven-year prospective follow-up. J Hepatol 2012;56:1145-51.

[42] Mathurin P, Gonzalez F, Kerdraon O, Leteurtre E, Arnalsteen L, Hollebecque A, et al. The evolution of severe steatosis after bariatric surgery is related to insulin resistance. Gastroenterology 2006;130:1617-24. 
[43] Mathurin P, Hollebecque A, Arnalsteen L, Buob D, Leteurtre E, Caiazzo R, et al. Prospective study of the long-term effects of bariatric surgery on liver injury in patients without advanced disease. Gastroenterology 2009;137:532-40.

[44] Rabl C, Campos GM. The impact of bariatric surgery on nonalcoholic steatohepatitis. Semin Liver Dis 2012;32:80-91.

[45] Vilar-Gomez E, Martinez-Perez Y, Calzadilla-Bertot L, Torres-Gonzalez A, Gra-Oramas B, Gonzalez-Fabian L, et al. Weight loss through lifestyle modification significantly reduces features of nonalcoholic steatohepatitis. 2015;149:367-78.e5.

[46] Hagström H, Stål P, Hultcrantz R, Hemminigsson T, Andreasson A. Overweight in late adolescence predicts development of severe liver disease later in life: A 39years follow-up study. J Hepatol 2016;65:363-8.

[47] Liu B, Balkwill A, Reeves G, Beral V. Body mass index and risk of liver cirrhosis in middle aged UK women: prospective study. BMJ 2010;340:c912.

[48] Ioannou GN, Weiss NS, Kowdley KV, Dominitz JA. Is obesity a risk factor for cirrhosisrelated death or hospitalization? A population-based cohort study. Gastroenterology 2003;125:1053-9.

[49] Calle EE, Rodriguez C, Walker-Thurmond K, Thun MJ. Overweight, obesity, and mortality from cancer in a prospectively studied cohort of U.S. adults. N Engl J Med 2003;348:1625-38.

[50] Hagström H, Tynelius P, Rasmussen F. High BMI in late adolescence predicts future severe liver disease and hepatocellular carcinoma: a national, population-based cohort study in 1.2 million men. Gut 2018;67:1536-42. 
[51] Argo CK, Henry ZH. Editorial: “Lean” NAFLD: metabolic obesity with normal BMI... is it in the genes? Am J Gastroenterol 2017;112:111-3.

[52] Bhat G, Baba CS, Pandey A, Kumari N, Choudhuri G. Insulin resistance and metabolic syndrome in nonobese Indian patients with non-alcoholic fatty liver disease. Trop Gastroenterol 2013;34:18-24.

[53] Nishioji K, Sumida Y, Kamaguchi M, Mochizuki N, Kobayashi M, Nishimura T, et al. Prevalence of and risk factors for nonalcoholic fatty liver disease in a non-obese Japanese population, 2011-2012. J Gastroenterol 2015;50:95-108.

[54] Feng RN, Du SS, Wang C, Li YC, Liu LY, Guo FC, et al. Lean-non-alcoholic fatty liver disease increases risk for metabolic disorders in a normal weight Chinese population. World J Gastroenterol 2014;20:17932-40.

[55] Margariti E, Deutsch M, Manolakopoulos S, Papatheodoridis GV. Non-alcoholic fatty liver disease may develop in individuals with normal body mass index. Ann Gastroenterol 2012;25:45-51.

[56] Kim HJ, Kim HJ, Lee KE, Kim DJ, Kim SK, Ahn CW, et al. Metabolic significance of nonalcoholic fatty liver disease in nonobese, nondiabetic adults. Arch Intern Medicine 2004;164:2169-75.

[57] Younossi ZM, Stepanova M, Negro F, Hallaji S, Younossi Y, Lam B, et al. Nonalcoholic fatty liver disease in lean individuals in the United States. Medicine 2012;91:319-27.

[58] Chen F, Esmaili S, Rogers G, Bugianesi E, Petta S, Marchesini G, et al. Lean NAFLD: A distinct entity shaped by differential metabolic adaptation [published online ahead of print, 2019 Aug 23]. Hepatology. 2019;10.1002/hep.30908. doi:10.1002/hep.30908 
[59] Hagström H, Nasr P, Ekstedt M, Hammar U, Stål P, Hultcrantz R, et al. Risk for development of severe liver disease in lean patients with nonalcoholic fatty liver disease: A long-term follow-up study. Hepatol Commun. 2017;2:48-57.

[60] Orci LA, Gariani K, Oldani G, Delaune V, Morel P, Toso C. Exercise-based interventions for nonalcoholic fatty liver disease: a meta-analysis and meta-regression. Clin Gastroenterol Hepatol 2016;14:1398-1411.

[61] Katsagoni CN, Georgoulis M, Papatheodoridis GV, Panagiotakos DB, Kontogianni MD. Effects of lifestyle interventions on clinical characteristics of patients with non-alcoholic fatty liver disease: a meta-analysis. Metabolism 2017;68:119-32.

[62] Oh S, Shida T, Yamagishi K, Tanaka K, So R, Tsujimoto T, et al. Moderate to vigorous physical activity volume is an important factor for managing nonalcoholic fatty liver disease: a retrospective study. Hepatology 2015;61:1205-15.

[63] Thoma C, Day CP, Trenell MI. Lifestyle interventions for the treatment of non-alcoholic fatty liver disease in adults: a systematic review. J Hepatol 2012;56:255-66.

[64] Keating SE, Hackett DA, George J, Johnson NA. Exercise and non-alcoholic fatty liver disease: a systematic review and meta-analysis. J Hepatol 2012;57:157-66.

[65] Collaboration NCDRF. Worldwide trends in diabetes since 1980: a pooled analysis of 751 population-based studies with 4.4 million participants. Lancet 2016;387:1513-30.

[66] Younossi ZM, Gramlich T, Matteoni CA, Boparai N, McCullough AJ. Nonalcoholic fatty liver disease in patients with type 2 diabetes. Clin Gastroenterol Hepatol 2004;2:262-5.

[67] Hossain N, Afendy A, Stepanova M, Nader F, Srishord M, Rafiq N, et al. Independent predictors of fibrosis in patients with nonalcoholic fatty liver disease. Clin Gastroenterol Hepatol 2009;7;1224-9, 1229.e1-2. 
[68] Stepanova M, Rafiq N, Makhlouf H, Agrawal R, Kaur I, Younoszai Z, et al. Predictors of all-cause mortality and liver-related mortality in patients with non-alcoholic fatty liver disease (NAFLD). Dig Dis Sci 2013;58:3017-23.

[69] Fracanzani AL, Valenti L, Bugianesi E, Andreoletti M, Colli A, Vanni E, et al. Risk of severe liver disease in nonalcoholic fatty liver disease with normal aminotransferase levels: a role for insulin resistance and diabetes. Hepatology 2008;48:792-8.

[70] Mofrad P, Contos MJ, Haque M, Sargeant C, Fisher RA, Luketic VA, et al. Clinical and histologic spectrum of nonalcoholic fatty liver disease associated with normal ALT values. Hepatology 2003;37:1286-1292.

[71] Williams CD, Stengel J, Asike MI, Torres DM, Shaw J, Contreras M, et al. Prevalence of nonalcoholic fatty liver disease and nonalcoholic steatohepatitis among a largely middle-aged population utilizing ultrasound and liver biopsy: A prospective study. Gastroenterology 2011;140:124-31.

[72] Anstee QM, Targher G, Day CP. Progression of NAFLD to diabetes mellitus, cardiovascular disease or cirrhosis. Nat Rev Gastroenterol Hepatol 2013;10:330-44.

[73] Björkström K, Stål P, Hultcrantz R, Hagström H. Histologic scores for fat and fibrosis associate with development of type 2 diabetes in patients with nonalcoholic fatty liver disease. Clin Gastroenterol Hepatol 2017;15:1461-8.

[74] Park SK, Seo MH, Shin HC, Ryoo JH. Clinical availability of nonalcoholic fatty liver disease as an early predictor of type 2 diabetes mellitus in Korean men: 5-year prospective cohort study. Hepatology 2013;57:1378-83.

[75] Ma J, Hwang S-J, Pedley A, Massaro JM, Hoffmann U, Chung RT, et al. Bi-directional analysis between fatty liver and cardiovascular disease risk factors. J Hepatol 2017;66:390-7. 
[76] Li Y, Wang J, Tang Y, Han X, Liu B, Hu H, et al. Bidirectional association between nonalcoholic fatty liver disease and type 2 diabetes in Chinese population: Evidence from the Dongfeng-Tongji cohort study. PLoS One 2017;12:e0174291.

[77] Lonardo A, Bellentani S, Argo CK, Ballestri S, Byrne CD, Caldwell SH, et al. Epidemiological modifiers of non-alcoholic fatty liver disease: Focus on high-risk groups. Dig Liver Dis 2015;47:997-1006.

[78] Younossi ZM, Golabi P, de Avila L, Paik JM, Srishord M, Fukui N, et al. The global epidemiology of NAFLD and NASH in patients with type 2 diabetes: A systematic review and meta-analysis. J Hepatol 2019;71:793-801.

[79] Bril F, Cusi K. Management of nonalcoholic fatty liver disease in patients with type 2 diabetes: a call to action. Diabetes Care 2017;40:419-30.

[80] Hazlehurst JM,Woods C,Marjot T, Cobbold JF, Tomlinson JW. Non-alcoholic fatty liver disease and diabetes. Metabolism 2016;65:1096-108.

[81] Ballestri S, Zona S, Targher G, Romagnoli D, Baldelli E, Nascimbeni F, et al. Nonalcoholic fatty liver disease is associated with an almost two-fold increased risk of incident type 2 diabetes and metabolic syndrome. Evidence from a systematic review and meta-analysis. J Gastroenterol Hepatol 2016:31:936-44.

[82] Chen SC, Tsai SP, Jhao JY, Jiang WK, Tsao CK, Chang LY. Liver fat, hepatic enzymes, alkaline phosphatase and the risk of incident type 2 diabetes: A prospective study of 132,377 adults. Sci Rep 2017;7:4649.

[83] McPherson S, Hardy T, Henderson E, Burt AD, Day CP, Anstee QM et al. Evidence of NAFLD progression from steatosis to fibrosing-steatohepatitis using paired biopsies: Implications for prognosis and clinical management. J Hepatol 2015:62;1148-55. 
[84] Adams LA, Harmsen S, St Sauver JL, Charatcharoenwitthaya P, Enders FB, Therneau T, et al. Nonalcoholic fatty liver disease increases risk of death among patients with diabetes: a community-based cohort study. Am J Gastroenterol 2010;105:1567-73.

[85] Sebastiani G, Alshaalan R, Wong P, Rubino M, Salman A, Metrakos P, et al. Prognostic value of non-invasive fibrosis and steatosis tools, hepatic venous pressure gradient (HVPG) and histology in nonalcoholic steatohepatitis. PLoS One 2015;10:e0128774.

[86] Vilar-Gomez E, Calzadilla-Bertot L, Wai-Sun Wong V, Castellanos M, Aller-de la Fuente R, Metwally M, et al. Fibrosis severity as a determinant of cause-specific mortality in patients with advanced nonalcoholic fatty liver disease: a multi-national cohort study. Gastroenterology 2018;155:443-57. e17.

[87] Wideroff L, Gridley G, Mellemkjaer L, Chow WH, Linet M, Keehn S, et al. Cancer incidence in a population-based cohort of patients hospitalized with diabetes mellitus in Denmark. J Natl Cancer Inst 1997;89:1360-5.

[88] Yu MC, Tong MJ, Govindarajan S, Henderson BE. Nonviral risk factors for hepatocellular carcinoma in a low-risk population, the non-Asians of Los Angeles County, California. J Natl Cancer Inst 1991;83:1820-6.

[89] Kingston M, Ali MA, Atiyeh M, Donnelly RJ. Diabetes mellitus in chronic active hepatitis and cirrhosis. Gastroenterology 1984;87:688-94.

[90] El-Serag HB, Tran T, Everhart JE. Diabetes increases the risk of chronic liver disease and hepatocellular carcinoma. Gastroenterology 2004;126:460-8.

[91] Davila J, Morgan R, Shaib Y, McGlynn KA, El-Serag HB. Diabetes increases the risk of hepatocellular carcinoma in the United States: a population based case control study. Gut 2005;54:533-9. 
[92] Dyson J, Jaques B, Chattopadyhay D, Lochan R, Graham J, Das D, et al. Hepatocellular cancer: the impact of obesity, type 2 diabetes and a multidisciplinary team. J Hepatol 2014;60:110-7.

[93] Singh S, Allen AM, Wang Z, Prokop LJ, Murad MH, Loomba R. Fibrosis progression in nonalcoholic fatty liver vs nonalcoholic steatohepatitis: A systematic review and meta-analysis of paired-biopsy studies. Clin Gastroenterol Hepatol 2015;13:643-54.

[94] Liao XH, Cao X, Liu J, Xie XH, Sun YH, Zhong BH. Prevalence and features of fatty liver detected by physical examination in Guangzhou. World J Gastroenterol 2013;19:5334-9.

[95] Männistö VT, Simonen M, Soininen P, Tiainen M, Kangas AJ, Kaminska D, et al. Lipoprotein subclass metabolism in nonalcoholic steatohepatitis. J Lipid Res 2014;55:267684.

[96] Corey KE, Lai M, Gelrud LG, Misdraji J, Barlow LL, Zheng H, et al. Non-high-density lipoprotein cholesterol as a biomarker for nonalcoholic steatohepatitis. Clin Gastroenterol Hepatol 2012;10:651-6.

[97] Siddiqui MS, Fuchs M, Idowu M, Luketic VA, Boyett S, Sargeant C, et al. Severity of nonalcoholic fatty liver disease and progression to cirrhosis associate with atherogenic lipoprotein profile. Clin Gastroenterol Hepatol 2015;13:1000-8.

[98] Bhala N, Angulo P, van der Poorten D, Lee E, Hui JM, saracco G, et al. The natural history of nonalcoholic fatty liver disease with advanced fibrosis or cirrhosis: an international collaborative study. Hepatology 2011;54:1208-16.

[99] Loria P, Marchesini G, Nascimbeni F, Ballestri S, Maurantonio M, Carubbi F, et al. Cardiovascular risk, lipidemic phenotype and steatosis. A comparative analysis of cirrhotic and non-cirrhotic liver disease due to varying etiology. Atherosclerosis 2014;232:99-109. 
[100] van der Poorten D, Samer CF, Ramezani-Moghadam M, Coulter S, Kacevska M, Schrijnders D, et al. Hepatic fat loss in advanced nonalcoholic steatohepatitis: are alterations in serum adiponectin the cause? Hepatology 2013;57:2180-8.

[101] Lee YH, Jung KS, Kim SU, Yoon HJ, Yun YJ, Lee BW, et al. Sarcopaenia is associated with NAFLD independently of obesity and insulin resistance: Nationwide surveys (KNHANES 2008-2011). J Hepatol 2015;63:486-93.

[102] Issa D, Alkhouri N, Tsien C, Shah S, Lopez R, McCullough, et al. Presence of sarcopenia (muscle wasting) in patients with nonalcoholic steatohepatitis. Hepatology 2014;60:428-9.

[103] Lee Y, Kim SU, Song K, Park JY, Kim DY, Ahn SH, et al. Sarcopenia is associated with significant liver fibrosis independently of obesity and insulin resistance in nonalcoholic fatty liver disease: nationwide surveys (KNHANES 2008-2011). Hepatology 2016;63:77686.

]104] Petta S, Ciminnisi S, Di Marco V, Cabibi D, Camma C, Licata A, et al. Sarcopenia is associated with severe liver fibrosis in patients with non-alcoholic fatty liver disease. Aliment Pharmacol Ther 2017;45: 510-8.

[105] Kim W, Koo BK, Joo SK, Kim JH, Park SC. Sarcopenia is an independent risk factor for biopsy-proven non-alcoholic steatohepatitis. J Hepatol 2016;64:S502.

[106] Koo BK, Kim D, Joo SK, Kim JH, Chang MS, Kim BG, et al. Sarcopenia is an independent risk factor for non-alcoholic steatohepatitis and significant fibrosis. J Hepatol 2017;66:123-31.

[107] Tarantino G, Conca P, Riccio A, Tarantino M, di Minno MN, Chianese D, et al. Enhanced serum concentrations of transforming growth factor- $\beta 1$ in simple fatty liver: Is it really benign? J Transl Med 2008;6:72. 
[108] Adams LA, Lymp JF, Sauver JS, Sanderson SO, Lindor KD, Feldstein A, et al. The natural history of nonalcoholic fatty liver disease: A population-based cohort study. Gastroenterology 2005;129:113-21.

[109] Williams R, Aspinall R, Bellis M Camps-Walsh G, Cramp M, Dhawan A, et al. Addressing liver disease in the UK: a blueprint for attaining excellence in health care and reducing premature mortality from lifestyle issues of excess consumption of alcohol, obesity, and viral hepatitis. Lancet 2014;384:1953-97.

[110] European Association for the Study of the Liver, European Association for the Study of Diabetes, European Association for the Study of Obesity. EASL-EASD-EASO Clinical Practice Guidelines for the management of non-alcoholic fatty liver disease. J Hepatol 2016;64:1388-402.

[111] Becker U, Deis A, Sørensen T, Grønbaek M, Borch-Johnsen K, Müller CF. et al. Prediction of risk of liver disease by alcohol intake, sex, and age: a prospective population study. Hepatology 1996;23:1025-9.

[112] Adams LA, Anstee QM, Tilg H, Targher G. Non-alcoholic fatty liver disease and its relationship with cardiovascular disease and other extrahepatic diseases. Gut 2017;66:1138-53.

[113] Schrieks IC, Heil AL, Hendriks HF, Mukamal KJ, Beulens JW. The effect of alcohol consumption on insulin sensitivity and glycemic status: a systematic review and meta-analysis of intervention studies. Diabetes Care 2015;38:723-32.

[114] Cao G, Yi T, Liu Q, Wang M, Tang S. Alcohol consumption and risk of fatty liver disease: a meta-analysis. PeerJ 2016;4:e2633.

[115] Moriya A, Iwasaki Y, Ohguchi S, Kayashima E, Mitsumune T, Taniguchi H, et al. Roles of alcohol consumption in fatty liver: a longitudinal study. J Hepatol 2015;62:921-7. 
[116] Kechagias S, Zanjani S, Gjellan S, Leinhard OD, Kihlberg J, Smedby Ö, et al. Effects of moderate red wine consumption on liver fat and blood lipids: a prospective randomized study. Ann Med 2011;43:545-54.

[117] Dunn W, Sanyal AJ, Brunt EM, Unalp-Arida A, Donohue M, McCullough AJ, et al. Modest alcohol consumption is associated with decreased prevalence of steatohepatitis in patients with non-alcoholic fatty liver disease (NAFLD). J Hepatol 2012;57:384-91.

[118] Hagström H, Nasr P, Ekstedt M, Kechagias S,Önnerhag K, Nilsson E, et al. Low to moderate lifetime alcohol consumption is associated with less advanced stages of fibrosis in non-alcoholic fatty liver disease. Scand J Gastroenterol 2017;52:159-65.

[119] Ekstedt M, Franzén LE, Holmqvist M, Bendtsen P, Mathiesen UL, Bodemar G, et al. Alcohol consumption is associated with progression of hepatic fibrosis in non-alcoholic fatty liver disease. Scand J Gastroenterol 2009;44:366-74.

[120] Ajmera V, Belt P, Wilson LA, Gill RM, Loomba R, Kleiner DE, et al. Among patients with nonalcoholic fatty liver disease, modest alcohol use is associated with less improvement in histologic steatosis and steatohepatitis. Clin Gastroenterol Hepatol 2018;16:1511-20. e5.

[121] Kimura T, Tanaka N, Fujimori N, Sugiura A, Yamazaki T, Joshita S, et al. Mild drinking habit is a risk factor for hepatocarcinogenesis in non-alcoholic fatty liver disease with advanced fibrosis. World J Gastroenterol 2018;24:1440-50.

[122] Dixon JB, Bhathal PS, O'Brien PE. Nonalcoholic fatty liver disease: predictors of nonalcoholic steatohepatitis and liver fibrosis in the severely obese. Gastroenterology 2001;121:91-100. 
[123] Cotrim HP, Freitas LA, Alves E, Almeida A, May DS, Caldwell S. Effects of light-tomoderate alcohol consumption on steatosis and steatohepatitis in severely obese patients. Eur J Gastroenterol Hepatol 2009;21:969-72.

[124] Ascha MS, Hanouneh IA, Lopez R, Tamimi TA, Feldstein AF, Zein NN. The incidence and risk factors of hepatocellular carcinoma in patients with nonalcoholic steatohepatitis. Hepatology 2010;51:1972-8.

[125] Kwon HK, Greenson JK, Conjeevaram HS. Effect of lifetime alcohol consumption on the histological severity of non-alcoholic fatty liver disease. Liver Int 2014;34:129-35.

[126] Sookoian S, Flichman D, Castaño GO, Pirola CJ. Mendelian randomisation suggests no beneficial effect of moderate alcohol consumption on the severity of nonalcoholic fatty liver disease. Aliment Pharmacol Ther 2016;44:1224-34.

[127] Yamada K, Mizukoshi E, Seike T, Horii R, Kitahara M, Sunagozaka H. Light alcohol consumption has the potential to suppress hepatocellular injury and liver fibrosis in nonalcoholic fatty liver disease. PloS one 2018;13:e0191026.

[128] Mitchell T, Jeffrey GP, de Boer B, MacQuillan G, Garas G, Ching H, et al. Type and pattern of alcohol consumption is associated with liver fibrosis in patients with non-alcoholic fatty liver disease. Am J Gastroenterol 2018;113:1484-93.

[129] Hajifathalian K, Torabi Sagvand B, McCullough AJ. Effect of alcohol consumption on survival in nonalcoholic fatty liver disease: A National Prospective Cohort Study. Hepatology 2019;70:511-21.

[130] Ronksley PE, Brien SE, Turner BJ, Mukamal KJ, Ghali WA. Association of alcohol consumption with selected cardiovascular disease outcomes: a systematic review and metaanalysis. BMJ 2011;342:d671. 
[131] Chang Y, Cho YK, Kim Y, Sung E, Ahn J, Jung HS, et al. Nonheavy drinking and worsening of noninvasive fibrosis markers in nonalcoholic fatty liver disease: A Cohort Study. Hepatology 2019;69:64-75.

[132] Mahli A, Hellerbrand C. Alcohol and obesity: a dangerous association for fatty liver disease. Dig Dis 2016;34:32-9.

[133] Romeo S, Kozlitina J, Xing C, Pertsemlidis A, Cox D, Pennacchio LA, et al. Genetic variation in PNPLA3 confers susceptibility to nonalcoholic fatty liver disease. Nat Genet 2008;40:1461-5.

[134] Speliotes EK, Butler JL, Palmer CD, Voight BF. PNPLA3 variants specifically confer increased risk for histologic nonalcoholic fatty liver disease but not metabolic disease. Hepatology 2010;52:904-12.

[135] Kozlitina J, Smagris E, Stender S, Nordestgaard BG, Zhou HH, Tybjaerg-Hansen A, et al. Exome-wide association study identifies a TM6SF2 variant that confers susceptibility to nonalcoholic fatty liver disease. Nat Genet 2014;46:352-6.

[136] Kawaguchi T, Sumida Y, Umemura A, Matsuo K, Takahashi M, Takamura T, et al. Genetic polymorphisms of the human PNPLA3 gene are strongly associated with severity of non-alcoholic fatty liver disease in Japanese. PLoS one 2012;7:e38322.

[137] Trepo E, Guyot E, Ganne-Carrie N, Degre D, Gustot T, Franchimont D, et al. PNPLA3 (rs738409 C> G) is a common risk variant associated with hepatocellular carcinoma in alcoholic cirrhosis. Hepatology 2012;55:1307-8.

[138] Trépo E, Nahon P, Bontempi G, Valenti L, Falleti E, Nischalke HD, et al. Association between the PNPLA3 (rs738409 C> G) variant and hepatocellular carcinoma: evidence from a meta-analysis of individual participant data. Hepatology 2014;59:2170-7. 
[139] Liu YL, Patman G, Leathart J, Piguet AC, Burt AD, Dufour JF, et al. Carriage of the PNPLA3 rs738409 C> G polymorphism confers an increased risk of non-alcoholic fatty liver disease associated hepatocellular carcinoma. J Hepatol 2014;61:75-81.

[140] Mancina RM, Dongiovanni P, Petta S, Pingitore P, Meroni M, Rametta R, et al. The MBOAT7-TMC4 variant rs641738 increases risk of nonalcoholic fatty liver disease in individuals of European descent. Gastroenterology 2016;150:1219-30. e6.

[141] Sookoian S, Flichman D, Garaycoechea ME, Gazzi C, Martino JS, Castaño GO, et al. Lack of evidence supporting a role of TMC4-rs641738 missense variant-MBOAT7-intergenic downstream variant—in the Susceptibility to Nonalcoholic Fatty Liver Disease. Sci Rep 2018;8:5097.

[142] Speliotes EK, Yerges-Armstrong LM, Wu J, Hernaez R, Kim LJ, Palmer CD, et al. Genome-wide association analysis identifies variants associated with nonalcoholic fatty liver disease that have distinct effects on metabolic traits. PLoS genetics 2011;7:e1001324.

[143] Chambers JC, Zhang W, Sehmi J, Li X, Wass MN, Van der Harst P, et al. Genome-wide association study identifies loci influencing concentrations of liver enzymes in plasma. Nat Genet 2011;43:1131-8.

[144] Eslam M, Valenti L, Romeo S. Genetics and epigenetics of NAFLD and NASH: Clinical impact. J Hepatol 2018;68:268-79.

[145] Bacon BR, Farahvash MJ, Janney CG, Neuschwander-Tetri BA. Nonalcoholic steatohepatitis: an expanded clinical entity. Gastroenterology 1994;107:1103-9.

[146] Nelson JE, Wilson L, Brunt EM, Yeh MM, Kleiner DE, Unalp-Arida A, et al. Relationship between the pattern of hepatic iron deposition and histological severity in nonalcoholic fatty liver disease. Hepatology 2011;53:448-57. 
[147] Fargion S, Mattioli M, Fracanzani AL, Sampietro M, Tavazzi D, Fociani P, et al. Hyperferritinemia, iron overload, and multiple metabolic alterations identify patients at risk for nonalcoholic steatohepatitis. Am J Gastroenterol 2001;96:2448-55.

[148] Bugianesi E, Manzini P, D'Antico S, Vanni E, Longo F, Leone N, et al. Relative contribution of iron burden, HFE mutations, and insulin resistance to fibrosis in nonalcoholic fatty liver. Hepatology 2004;39:179-87.

[149] Manousou P, Kalambokis G, Grillo F, Watkins J, Xirouchakis E, Pleguezuelo M. et al. Serum ferritin is a discriminant marker for both fibrosis and inflammation in histologically proven non-alcoholic fatty liver disease patients. Liver Int 2011;31:730-9.

[150] Fracanzani AL, Valenti L, Bugianesi E, Vanni E, Grieco A, Miele L, et al. Risk of nonalcoholic steatohepatitis and fibrosis in patients with nonalcoholic fatty liver disease and low visceral adiposity. J Hepatol 2011;54:1244-9.

[151] Kowdley KV, Belt P, Wilson LA, Yeh MM, Neuschwander-Tetri BA, Chalasani N, et al. Serum ferritin is an independent predictor of histologic severity and advanced fibrosis in patients with nonalcoholic fatty liver disease. Hepatology 2012;55:77-85.

[152] Hagström H, Nasr P, Bottai M, Ekstedt M, Kechagias S, Hultcrantz R, et al. Elevated serum ferritin is associated with increased mortality in non-alcoholic fatty liver disease after 16 years of follow-up. Liver Int 2016;36:1688-95.

[153] Angulo P, George J, Day CP, Vanni E, Russell L, De la Cruz AC, et al. Serum ferritin levels lack diagnostic accuracy for liver fibrosis in patients with nonalcoholic fatty liver disease. Clin Gastroenterol Hepatol 2014;12:1163-9. e1. 
[154] Valenti L, Fracanzani AL, Bugianesi E, Dongiovanni P, Galmozzi E, Vanni E, et al. HFE genotype, parenchymal iron accumulation, and liver fibrosis in patients with nonalcoholic fatty liver disease. Gastroenterology 2010;138:905-12.

[155] Valenti L, Fracanzani AL, Dongiovanni P, Bugianesi E, Marchesini G, Manzini P, et al. Iron depletion by phlebotomy improves insulin resistance in patients with nonalcoholic fatty liver disease and hyperferritinemia: evidence from a case-control study. Am J Gastroenterol 2007;102:1251-8.

[156] Valenti L, Fracanzani AL, Dongiovanni P, Rovida S, Rametta R, Fatta E, et al. A randomized trial of iron depletion in patients with nonalcoholic fatty liver disease and hyperferritinemia. World J Gastroenterol 2014;20:3002-10.

[157] Sumida Y, Kanemasa K, Fukumoto K, Yoshida N, Sakai K, Nakashima T, et al. Effect of iron reduction by phlebotomy in Japanese patients with nonalcoholic steatohepatitis: A pilot study. Hepatol Res 2006;36:315-21.

[158] Beaton M, Chakrabarti S, Levstik M, Speechley M, Marotta P, Adams P. Phase II clinical trial of phlebotomy for non-alcoholic fatty liver disease. Aliment Pharmacol Ther 2013;37:7209.

[159] Adams LA, Crawford DH, Stuart K, House MJ, St Pierre TG, Webb M, et al. The impact of phlebotomy in nonalcoholic fatty liver disease: A prospective, randomized, controlled trial. Hepatology 2015;61:1555-64.

[160] de Serres FJ, Blanco I, Fernández-Bustillo E. PI S and PI Z alpha-1 antitrypsin deficiency worldwide. A review of existing genetic epidemiological data. Monaldi Arch for Chest Dis 2007;67:184-208. 
[161] Valenti L, Dongiovanni P, Piperno A, Fracanzani AL, Maggioni M, Rametta R, et al. $\alpha 1$ Antitrypsin mutations in NAFLD: high prevalence and association with altered iron metabolism but not with liver damage. Hepatology 2006;44:857-64.

[162] Goltz D, Hittetiya K, Vössing LM, Kirfel J, Spengler U, Fischer HP. a 1-Antitrypsin PiMZ heterozygosity has an independent aggravating effect on liver fibrosis in alcoholic liver disease. Virchows Arch 2014;465:539-46.

[163] Regev A, Guaqueta C, Molina EG, Conrad A, Mishra V, Brantly ML, et al. Does the heterozygous state of alpha-1 antitrypsin deficiency have a role in chronic liver diseases? Interim results of a large case-control study. Journal Pediatr Gastroenterol Nutr 2006;43:S30S5.

[164] Strnad P, Buch S, Hamesch K, Fischer J, Rosendahl J, Schmelz R, et al. Heterozygous carriage of the alpha1-antitrypsin $\mathrm{Pi}^{*} \mathrm{Z}$ variant increases the risk to develop liver cirrhosis. Gut 2019;68:1099-107.

[165] Babin PJ, Gibbons GF. The evolution of plasma cholesterol: direct utility or a spandrel of hepatic lipid metabolism? Prog Lipid Res 2009;48:73-91.

[166] Başaranoglu M, Ormeci N. Nonalcoholic fatty liver disease: diagnosis, pathogenesis, and management. Turk J Gastroenterol 2014;25:127-32.

[167] Haufe S, Engeli S, Kast P, Böhnke J, Utz W, Haas V, et al. Randomized comparison of reduced fat and reduced carbohydrate hypocaloric diets on intrahepatic fat in overweight and obese human subjects. Hepatology 2011;53:1504-14.

[168] Mensink RP, Zock PL, Kester AD, Katan MB. Effects of dietary fatty acids and carbohydrates on the ratio of serum total to HDL cholesterol and on serum lipids and apolipoproteins: a meta-analysis of 60 controlled trials. Am J Clin Nutr 2003;77:1146-55. 
[169] Abdelmalek MF, Suzuki A, Guy C, Unalp-Arida A, Colvin R, Johnson RJ, et al. Increased fructose consumption is associated with fibrosis severity in patients with nonalcoholic fatty liver disease. Hepatology 2010;51:1961-71.

[170] Maersk M, Belza A, Stødkilde-Jørgensen H, Ringgaard S, Chabanova E, Thomsen H, et al. Sucrose-sweetened beverages increase fat storage in the liver, muscle, and visceral fat depot: a 6-mo randomized intervention study. Am J Clin Nutr 2012;95:283-9.

[171] Tajima R, Kimura T, Enomoto A, Yanoshita K, Saito A, Kobayashi S, et al. Association between rice, bread, and noodle intake and the prevalence of non-alcoholic fatty liver disease in Japanese middle-aged men and women. Clin Nutr 2017;36:1601-8.

[172] Solga S, Alkhuraishe AR, Clark JM, Torbenson M, Greenwald A, Diehl AM, et al. Dietary composition and nonalcoholic fatty liver disease. Dig Dis Sci 2004;49:1578-83.

[173] Obara N, Fukushima K, Ueno Y, Wakui Y, Kimura O, Tamai K, et al. Possible involvement and the mechanisms of excess trans-fatty acid consumption in severe NAFLD in mice. J Hepatol 2010;53:326-34.

[174] Marchildon F, St-Louis C, Akter R. Transcription factor Smad3 is required for the inhibition of adipogenesis by retinoic acid. J Biol Chem 2010;285:13274- 84.

[175] Kwok RM, Torres DM, Harrison SA. Vitamin D and nonalcoholic fatty liver disease (NAFLD): is it more than just an association? Hepatology 2013;58 :1166-74. 
Table 1. NAFLD studies with paired biopsies.

\begin{tabular}{|c|c|c|c|c|c|}
\hline \multirow[b]{2}{*}{$\begin{array}{l}\text { Authors, year } \\
\text { [ref.] }\end{array}$} & \multirow[b]{2}{*}{$\mathbf{n}$} & \multirow[b]{2}{*}{$\begin{array}{l}\text { Follow-up time, years } \\
\text { (median (range)) }\end{array}$} & \multicolumn{3}{|c|}{ Baseline } \\
\hline & & & NASH & T2DM & $\begin{array}{l}\text { Predictors of } \\
\text { fibrosis } \\
\text { progression }\end{array}$ \\
\hline $\begin{array}{l}\text { Lee et al., } 1989 \\
\text { [20] }\end{array}$ & 13 & $3.3(1.2-6.9)$ & $100 \%$ & $54 \%$ & None \\
\hline $\begin{array}{l}\text { Powell et al., } \\
1990 \text { [21] }\end{array}$ & 13 & $3(1.5-6.5)$ & $100 \%$ & $46 \%$ & None \\
\hline $\begin{array}{l}\text { Teli et al., } 1995 \\
\text { [22] }\end{array}$ & 12 & 7.6-16 & $0 \%$ & N/A & N/A \\
\hline $\begin{array}{l}\text { Ratziu et al., } \\
2000 \text { [23] }\end{array}$ & 14 & $5(1.5-15)$ & $29 \%$ & N/A & N/A \\
\hline $\begin{array}{l}\text { Evans et al., } \\
2002 \text { [24] }\end{array}$ & 7 & $7(5.5-14)$ & N/A & $43 \%$ & N/A \\
\hline $\begin{array}{l}\text { Harrison et al., } \\
2003 \text { [25] }\end{array}$ & 22 & $5.7(1.4-15.7)$ & $41 \%$ & $41 \%$ & AST \\
\hline $\begin{array}{l}\text { Fassio et al., } \\
2004 \text { [26] }\end{array}$ & 22 & $4.3(3-14.3)$ & $100 \%$ & $36 \%$ & $\mathrm{BMI}$ \\
\hline $\begin{array}{l}\text { Adams et al., } \\
2005 \text { [27] }\end{array}$ & 103 & $3.2(0.7-21.3)$ & $93 \%$ & $42 \%$ & BMI, FS, T2DM \\
\hline $\begin{array}{l}\text { Hui et al., } \\
2005[28]\end{array}$ & 17 & $6.1(3.8-8)$ & $35 \%$ & $24 \%$ & None \\
\hline $\begin{array}{l}\text { Ekstedt et al., } \\
2006 \text { [29] }\end{array}$ & 68 & $13.8(10.3-16.3)$ & $49 \%$ & $9 \%$ & None \\
\hline $\begin{array}{l}\text { Wong et al., } \\
2010 \text { [30] }\end{array}$ & 52 & 3 & $33 \%$ & $50 \%$ & LDL \\
\hline $\begin{array}{l}\text { Pais et al., } \\
2013 \text { [31] }\end{array}$ & 70 & $3.4(1-12)$ & $64 \%$ & $35 \%$ & N/A \\
\hline $\begin{array}{l}\text { McPherson et } \\
\text { al., 2015 [32] }\end{array}$ & 108 & $6.6(1.3-22.6)$ & $75 \%$ & $48 \%$ & FIB-4 \\
\hline $\begin{array}{l}\text { Sanyal., } 2019 \\
\text { [33] }\end{array}$ & 475 & 1.8 & $71 \%$ & $68 \%$ & FS \\
\hline
\end{tabular}

Abbreviations: NASH, nonalcoholic steatohepatitis; T2DM, type 2 diabetes mellitus; AST, aspartate aminotransferase; BMI, body mass index; LDL, low-density lipoprotein; FIB-4, Fibrosis-4 (biochemical score for prediction of liver fibrosis); FS, fibrosis stage; N/A, not applicable. 
Table 2. Studies assessing the impact of alcohol on histopathology in NAFLD.

\begin{tabular}{|c|c|c|c|c|c|c|c|}
\hline $\begin{array}{l}\text { Authors, } \\
\text { year [ref.] }\end{array}$ & $\begin{array}{l}\text { Sample } \\
\text { size }\end{array}$ & $\begin{array}{l}\text { Diagnosis of } \\
\text { NAFLD }\end{array}$ & Study design & $\begin{array}{l}\text { Definition of } \\
\text { moderate } \\
\text { alcohol } \\
\text { consumption }\end{array}$ & $\begin{array}{l}\text { Assessment of } \\
\text { alcohol } \\
\text { consumption }\end{array}$ & Focus/highlight & Outcome \\
\hline $\begin{array}{l}\text { Dixon et } \\
\text { al., } 2001 \\
{[122]}\end{array}$ & 105 & Liver biopsy & Cross-sectional & <200 g/week & $\begin{array}{l}\text { Clinical } \\
\text { interview }+ \\
\text { questionnaire }\end{array}$ & Liver histology & $\begin{array}{l}\text { No significant } \\
\text { difference in NASH } \\
\text { after adjusting for } \\
\text { insulin resistance and } \\
\text { diabetes }\end{array}$ \\
\hline $\begin{array}{l}\text { Cotrim et } \\
\text { al., } 2009 \\
{[123]}\end{array}$ & 132 & Liver biopsy & Cross-sectional & $<280$ g/week & $\begin{array}{l}\text { Clinical } \\
\text { interview }\end{array}$ & Liver histology & $\begin{array}{l}\text { No difference in liver } \\
\text { histology }\end{array}$ \\
\hline $\begin{array}{l}\text { Ekstedt et } \\
\text { al., 2009 } \\
{[119]}\end{array}$ & 71 & Liver biopsy & Cohort & $<140$ g/week & $\begin{array}{l}\text { Clinical } \\
\text { interview }+ \\
\text { questionnaire } \\
\end{array}$ & Fibrosis progression & $\begin{array}{l}\text { Binge drinking was } \\
\text { associated with } \\
\text { higher fibrosis stage }\end{array}$ \\
\hline $\begin{array}{l}\text { Ascha et } \\
\text { al., } 2010 \\
{[124]}\end{array}$ & 195 & $\begin{array}{l}\text { Cirrhosis (liver } \\
\text { biopsy or } \\
\text { symptoms of } \\
\text { portal } \\
\text { hypertension) }\end{array}$ & Cohort & $<168$ g/week & Not stated & $\mathrm{HCC}$ & $\begin{array}{l}\text { Alcohol consumption } \\
\text { as a risk factor for } \\
\text { HCC }\end{array}$ \\
\hline $\begin{array}{l}\text { Dunn et } \\
\text { al., } 2012 \\
{[117]}\end{array}$ & 582 & Liver biopsy & Cross-sectional & $<140$ g/week & Questionnaire & $\begin{array}{l}\text { Liver histology, } \\
\text { steatohepatitis }\end{array}$ & $\begin{array}{l}\text { Less steatohepatitis } \\
\text { and fibrosis in } \\
\text { moderate consumers }\end{array}$ \\
\hline $\begin{array}{l}\text { Kwon et } \\
\text { al., } 2014 \\
{[125]}\end{array}$ & 77 & Liver biopsy & Cross-sectional & $<40$ g/week & Questionnaire & $\begin{array}{l}\text { Liver histology, lifetime } \\
\text { consumption }\end{array}$ & $\begin{array}{l}\text { Higher rate of } \\
\text { advanced fibrosis in } \\
\text { low/no consumption } \\
\text { group }\end{array}$ \\
\hline $\begin{array}{l}\text { Sookoian } \\
\text { et al., } 2016 \\
{[126]}\end{array}$ & 266 & Liver biopsy & $\begin{array}{l}\text { Cross- } \\
\text { sectional/mendelian } \\
\text { randomization }\end{array}$ & $\begin{array}{l}210 \text { g/week } \\
\text { (male) } 140 \\
\text { g/week (female) } \\
+ \text { gene carriers }\end{array}$ & $\begin{array}{l}\text { Clinical } \\
\text { interview }\end{array}$ & $\begin{array}{l}\text { Genetic carriers as a } \\
\text { measure of alcohol } \\
\text { consumption, no } \\
\text { protective association of } \\
\text { moderate consumption } \\
\text { on histology }\end{array}$ & $\begin{array}{l}\text { Higher rate of } \\
\text { steatosis and } \\
\text { inflammatory } \\
\text { changes in non- } \\
\text { carriers (i.e. drinkers) }\end{array}$ \\
\hline
\end{tabular}




\begin{tabular}{|c|c|c|c|c|c|c|c|}
\hline $\begin{array}{l}\text { Hagström } \\
\text { et al., 2017 } \\
\text { [118] }\end{array}$ & 120 & Liver biopsy & Cross-sectional & $168 \mathrm{~g} /$ week & $\begin{array}{l}\text { Questionnaire } \\
+ \text { PEth }\end{array}$ & Liver histology & $\begin{array}{l}\text { Reduced risk of } \\
\text { fibrosis in moderate } \\
\text { consumers. Elevated } \\
\text { PEth levels increased } \\
\text { risk of significant } \\
\text { fibrosis }\end{array}$ \\
\hline $\begin{array}{l}\text { Ajmera et } \\
\text { al., 2018 } \\
{[120]}\end{array}$ & 285 & Liver biopsy & Cohort & $<140$ g/week & $\begin{array}{l}\text { Clinical } \\
\text { interview + } \\
\text { questionnaire }\end{array}$ & Liver histology & $\begin{array}{l}\text { Greater reduction in } \\
\text { steatosis and NASH } \\
\text { in non-drinkers }\end{array}$ \\
\hline $\begin{array}{l}\text { Yamada et } \\
\text { al., 2018 } \\
{[127]}\end{array}$ & 178 & Liver biopsy & Cross-sectional & $\leq 140 \mathrm{~g} /$ week & Questionnaire & Liver histology & $\begin{array}{l}\text { Lower fibrosis score } \\
\text { in moderate } \\
\text { consumers }\end{array}$ \\
\hline $\begin{array}{l}\text { Mitchell et } \\
\text { al., 2018 } \\
\text { [128] }\end{array}$ & 187 & Liver biopsy & Cross-sectional & $\begin{array}{l}210 \mathrm{~g} / \text { week } \\
\text { (male) } 140 \\
\text { g/week (female) }\end{array}$ & $\begin{array}{l}\text { Clinical } \\
\text { interview }+ \\
\text { questionnaire }\end{array}$ & $\begin{array}{l}\text { Fibrosis, binge-drinking, } \\
\text { type of alcohol }\end{array}$ & $\begin{array}{l}\text { Less fibrosis among } \\
\text { subjects consuming } \\
\text { wine }<70 \mathrm{~g} / \mathrm{w} \text {, and in } \\
\text { non-binge drinkers }\end{array}$ \\
\hline $\begin{array}{l}\text { Kimura et } \\
\text { al., } 2018 \\
\text { [121] }\end{array}$ & 301 & Liver biopsy & Cohort & $<140$ g/week & $\begin{array}{l}\text { Clinical } \\
\text { interview }+ \\
\text { questionnaire }\end{array}$ & HCC & $\begin{array}{l}\text { Higher incidence of } \\
\text { HCC plus prevalence } \\
\text { of cirrhosis in } \\
\text { moderate consumers }\end{array}$ \\
\hline
\end{tabular}

Abbreviations: HCC, hepatocellular carcinoma; NASH, non-alcoholic steatohepatitis; PEth, phosphatidylethanol. 
Figure 1. Multiple hit model for the development of steatosis, inflammation and fibrosis. Dietary factors, together with obesity lead to increased levels of serum FFAs and development of insulin resistance through multiple factors. Secondary to obesity a subsequent adipocyte proliferation takes place, with augmentation of insulin resistance and increased levels of proinflammatory cytokines (TNF- $\alpha$, IL-6, and MCP-1) with decreasing or desensitized adipokines (adiponectin and leptin). The dysregulated adipokine and cytokine balance creates and maintains an inflammatory cascade and vicious circle and maintains the insulin resistance state. In the liver, insulin resistance amplifies de novo lipogenesis (DNL), decreases VLDL assembly and disrupts $\beta$-oxidation. The net sum, together with previously mentioned causes of raised serum FFA, is increased hepatic FFA influx. This leads to synthesis and accumulation of TG and toxic levels of FFAs. High levels of FFAs in the presence of reduced $\beta$-oxidation causes lipotoxicity and subsequently generation of ROS. This process is further enhanced in the presence of cytokines and attracted immune cells caused by the inflammatory milieu, inducing inflammation and cellular repair systems with secondary fibrosis.

Abbreviations: DNL, de novo lipogenesis; FFA, free fatty acid; IL-6, interleukin-6; JAK-STAT, janus kinase-signal transducer and activator of transcription proteins; JNK, c-Jun $\mathrm{NH}_{2}$-terminal kinase; MCP-1, monocyte chemoattractant protein-1; NASH, non-alcoholic steatohepatitis; NF$\kappa \beta$, nuclear factor- $\kappa \beta$; ROS, reactive oxygen species; TG, triglycerides; TNF- $\alpha$, tumor necrosis factor- $\alpha$. 
Figure 2. The relative distribution of NAFLD, NASH, cirrhosis, and hepatocellular carcinoma and factors influencing progression of NAFLD.

Prevalence data are from [4] and [71]. 


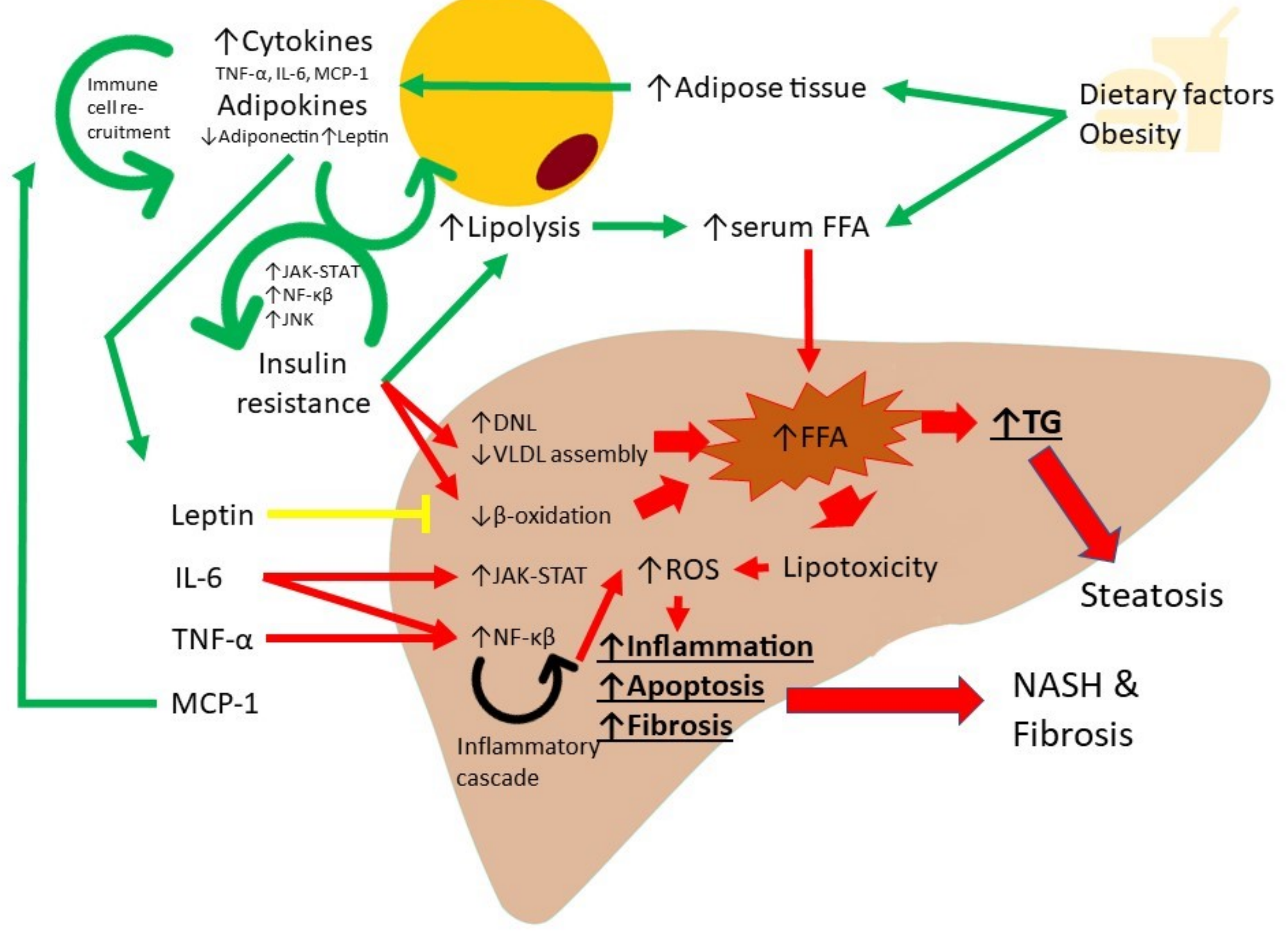




\section{Global prevalence}

$25 \%$ of adults

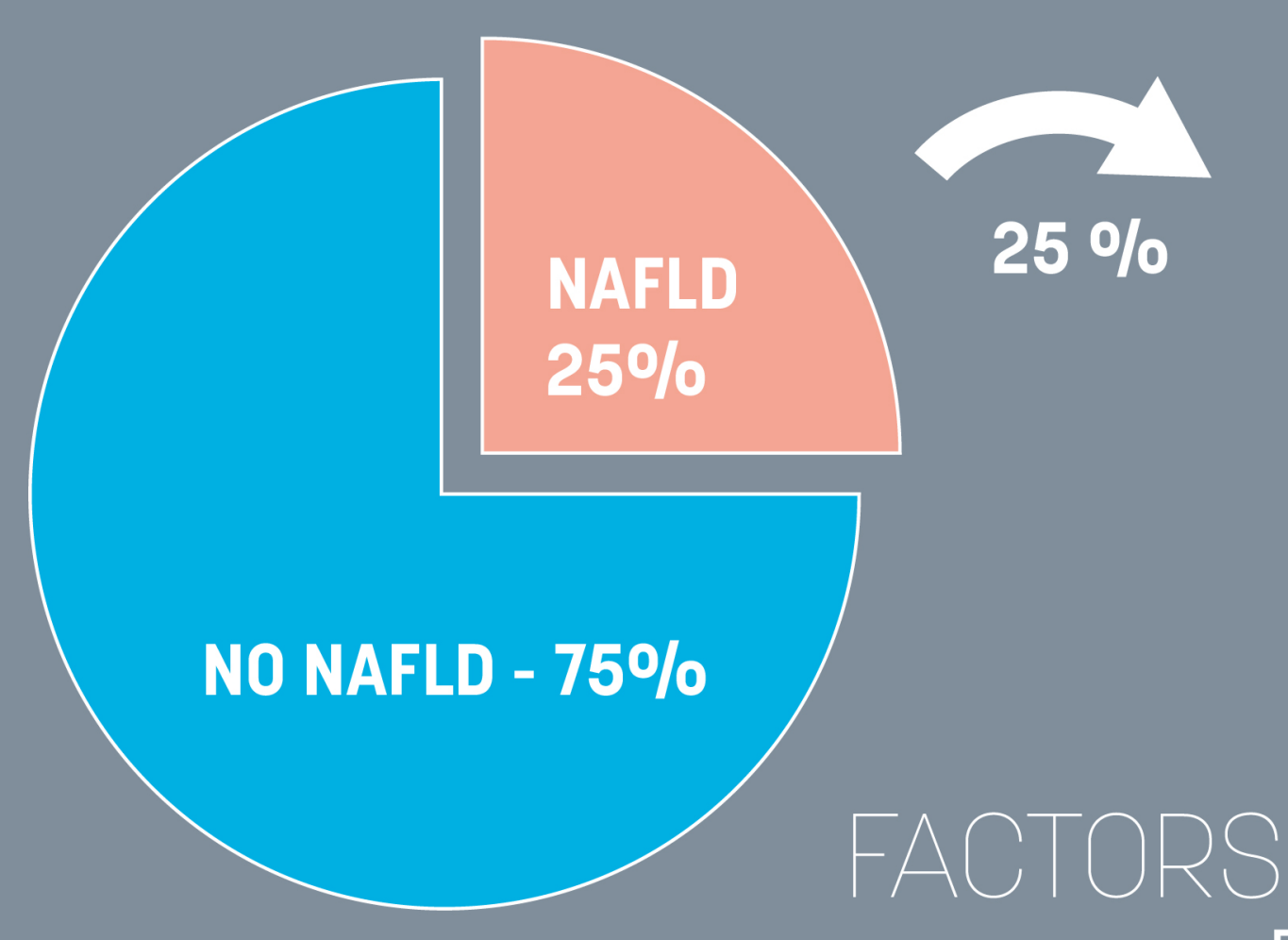

\section{5-6 $\%$ of adults $\quad 1-2 \%$ of adults}
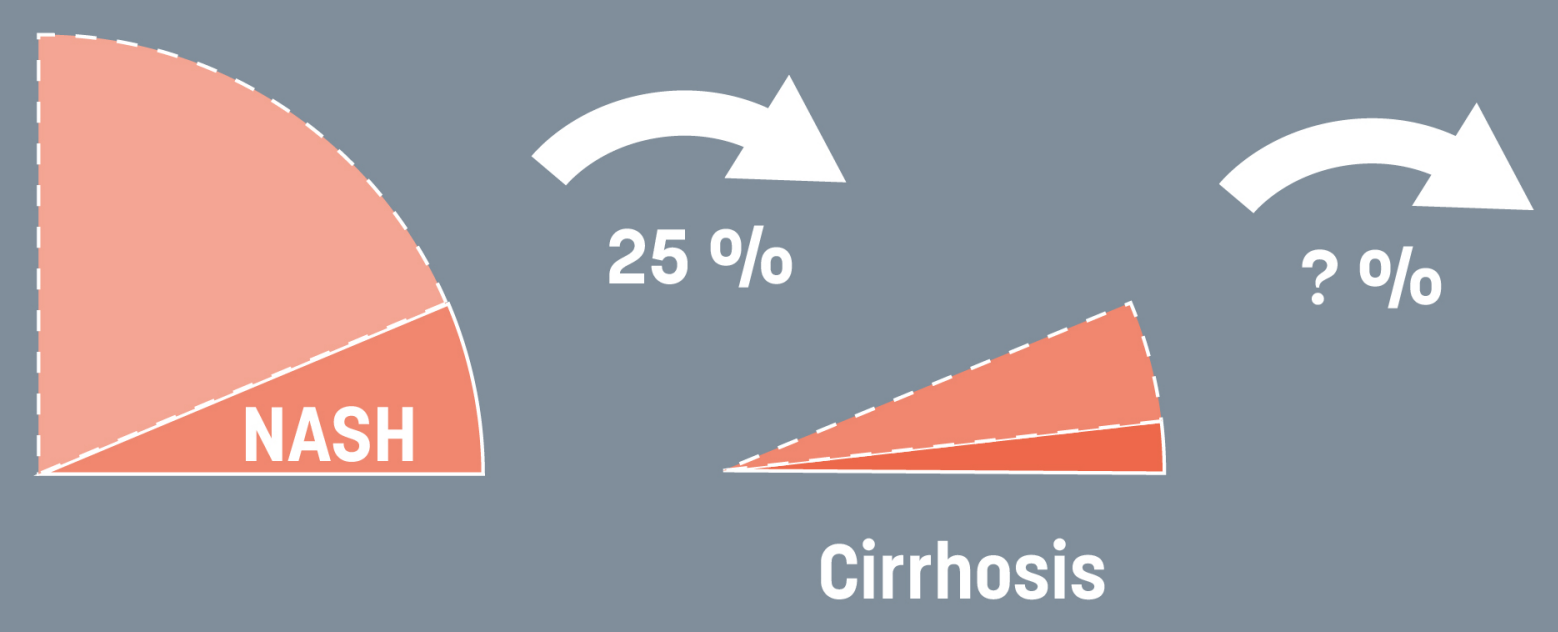

$? \%$

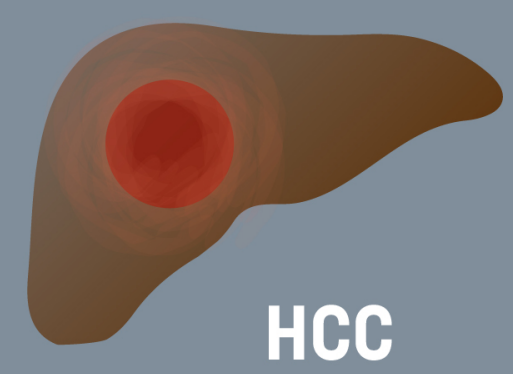

